\title{
An investigation on the effect of risk management on earnings volatility for shares of banks listed in Tehran Stock Exchange
}

\author{
Hamid Reza Kordlouie ${ }^{a}$, Leila Sadeghi ${ }^{b^{*}}$ and Nahid Sadeghi ${ }^{b}$
}

${ }^{a}$ Associate professor, Faculty of Accounting and Management, Eslamshahr Branch, Islamic Azad University, Iran

${ }^{b}$ Ph.D. Student in Accounting, Science and Research University, Qeshm International Center, Iran

\begin{tabular}{l}
\hline C H R O N I C L E \\
\hline Article history: \\
Received July 17, 2017 \\
Received in revised format \\
August 112017 \\
Accepted October 302017 \\
Available online \\
October 302017 \\
\hline Keywords: \\
Risk management \\
Earnings volatility \\
Bank \\
Tehran Stock Exchange
\end{tabular}

\section{Introduction}

In considering investment opportunities, attention is drawn to two categories of risk and return, and investors are assumed to be risk averse to returns. When investors face a risk in an investment, they adjust their position according to the degree of risk. In fact, many investors are looking for investment in low risk opportunities with relatively high degree of reward (Alijoyo, 2004). The risk of a company's market is measured by fluctuations in its stock returns and the stock price is also associated with the earnings per share (Beaver et al., 1970; Tang \& Musa, 2011). Therefore, companies tend to reduce return volatility by reducing fluctuations in profits, and ultimately affect investors' as well as creditors' perceptions of company risk. Therefore, companies aim at smoothing profits to reduce and shares volatility. Economic growth and increasing public welfare for the long run cannot be achieved without paying attention to important factors in the investment environment (Jensen \& Meckling, 1976). Risk

* Corresponding author.

E-mail address: leila_sadeghi4712@yahoo.com (L. Sadeghi)

2018 Growing Science Ltd.

doi: $10.5267 /$ j.ac.2017.10.001 
is one of the important factors influencing on decision making in association with investment. Investors are paying special attention to risk-taking in investment decisions (Hutton \& Stocken, 2009). Therefore, it is important to know the main factors that affect risk management. In this way, investors can plan their investment by considering important factors and their impacts, and achieve an optimal risk management. Reported profits are important financial information that is considered by decision makers. Financial analysts generally consider reported earnings as a prominent factor in their own judgments and judgments (Basu, 1997). Also, investors rely on their investment decisions based on the information provided in the financial statements of the economic units, in particular the reported statement. Based on the theoretical framework for financial reporting, the main financial reporting goals are to provide information for users to assess: the amount, timing and risk of future corporate cash flows (Kabir \& Hassan, 2005). The statement as a primary financial report is used to evaluate and forecast the future of the company. One of the key issues for users of financial statements is the company's future earnings forecast. Various factors in predicting future profits can be considered. It is important to determine and investigate the main factors for predicting future profits (Donelson et al., 2011).

Banks are organized as "profit-seeking organizations" and profitable for shareholders and depositors. Since risks to profitability are inevitable, banks are therefore referred to as "risky machines" (Hamilton, 1978). Accordingly, there are many risk factors in the banking industry for a variety of reasons such as diversity of banking operations, different nature of banking operations, the status of the bank's capital and its limitation, status of depositors and their abundance, differing interests of the bank and depositors, maturity of assets and liabilities, the multiplicity and difference of financial status of facilitators of the recipients, handling a large group of bank staff with financial resources and finally registration of high financial operations and large transfers (Boltz, 1999). Accordingly, in the bank and in the form of a risk committee, which is placed in the organizational structure under the supervision of the board of directors of the bank, the risks of credit, liquidity, market, operational, and other risks are controlled and managed. For identifying and managing operational risks, in addition to sign a contract with the audit firm on operational auditing, within the bank, some other inspections are held by organizing the audit committee and increasing inspections (Gul et al., 1997). Also, most banks try to reduce the risk of information technology by adapting electronic banking and incorporating the changes in information technology.

In general, risk management is the process of risk measurement or risk management, and then a strategy for risk management. In sum, the strategies used include: transferring risk to other sectors, avoiding risk, reducing the negative effects of risk, and accepting part or all of the consequences of a particular risk. Traditional risk management focuses on preventing risks from legal and physical causes such as natural disasters or fires, accidents, mortality and litigation (Ravindran et al., 2010). Financial risk management, on the other hand, focuses on the risks that could govern the use of financial and business tools. Intangible risk management focuses on risks associated with human capital, such as knowledge risk, relationship risk, and operational process risk. Regardless of the type of risk management, all large companies have risk management groups (Stulz, 2003). Graham et al. (2005) performed a survey among 400 financial managers and reported that 39 percent of the respondents favored a smooth and fluctuating profit and were not interested in fluctuating profits, 34 percent of them believed that fluctuations in profits could reduce the ability to predict future profits. According to Graham et al. (2005), profit as a major variable for stock valuation models is important, and past research has shown that profitability volatility reduces the ability to predict profits. Kolapo et al. (2012) performed an investigation on Nigerian firms over the period 2001-2010. In their survey, credit risk indices were classified in terms of three financial ratios, namely, the ratio of deferred payments to prepayments, the ratio of loans and prepayments to total deposits, and the ratio of doubtful receivables to loans. The results of the research showed that in general, credit risk and its indices had a significant effect on the performance of commercial banks. 
$\mathrm{Ni}$ et al. (2009) performed an investigation on the commercial banks in Thailand to find out whether the estimated financial risks have incremental information content beyond earnings. Analysts discovered that the earnings announcements influenced on the movement of the shares price. These findings indicated the relevant of the financial risk exposure in the Thailand banks using the latest data. Beaver et al. (2005) developed a model that disclose the distinct natures of and interactions between conditional and unconditional conservatism. Under unconditional conservatism, the book value of net assets was understated because of predetermined aspects of the accounting process. Under conditional conservatism, book value was written down under adverse circumstances, but not up under favorable circumstances. Frankel and Litov (2009) verified the incremental explanatory power of earning volatility and whether the predictive power of past earnings volatility was priced in stock returns. They also discussed motives for the study of earnings persistence. They reported that the relation between past earnings volatility and earnings persistence was strong to the additional controls and to a correction for sampling bias, but that earnings volatility would not forecast stock returns. Kabir and Hassan (2005) investigated the contagion and the so called "too-big-to-fail" hypotheses for the longterm capital management (LTCM) crisis in the US financial services industry. They reported that those commercial and investments banks exposed to LTCM lost market values substantially around vital events surrounding the near collapse of LTCM, but the losses experienced by investment banks were much higher than the losses encountered by commercial banks. Smaller S\&L institutions and bigger insurance companies were also influenced by the crisis, indicating a form of contagion impact in the financial sector. They also reported some evidence of a 'too-big-to-fail' policy with the involvement of the Fed in LTCM, as forecasted by the markets. Lewellen and Shanken (2002) investigated the asset-pricing implications of parameter uncertainty and reported that, when investors should learn about expected cash flows, empirical tests could determine patterns in the data that vary from those kept by rational investors. They also reported that parameter uncertainty plays essential role for characterizing and examining the market efficiency. Louis (2005) analyzed the impact of auditor choice on acquirers' market values around merger announcements and the factors influencing on the interaction between auditor size and the market reaction to the merger announcements. They reported that acquirers audited by the largest accounting firms substantially under-perform those audited by smaller firms at merger announcements.

\section{The proposed method}

This study aims to investigate the effect of risk management on profitability fluctuation on shares of banks listed in Tehran Stock Exchange. The statistical population includes all 20 listed banks in Tehran Stock Exchange over the period 2009-2015. As the number of listed banks in Tehran Stock Exchange was limited, census method and multiple regressions in panel data were used to collect the data and test the hypotheses, respectively. In this study, profitability fluctuation was calculated given in Dichev and Tang (2009). There are two hypotheses associated with the proposed study of this paper as follows,

1. Risk management has a significant effect on the volatility of earnings of accepted banks in Tehran Stock Exchange.

2. Stock return influences more on profit volatility of the banks accepted in Tehran Stock Exchange.

The proposed study considers the following equation to examine the hypotheses of the survey,

$$
\begin{aligned}
& \text { Earning Volaltility }_{i, t}=\alpha_{0}+\alpha_{1} \text { Risk management }_{i, t}+\alpha_{2} \text { Leverage }_{i, t}+\alpha_{3} \text { Size }_{i, t}+ \\
& \alpha_{4} \operatorname{DPR}_{i, t}+\alpha_{5} \text { RET }_{i, t}+\alpha_{6} \text { LIQ }_{i, t}+\varepsilon_{i, t}
\end{aligned}
$$

where Risk management $_{i, t}$, Leverage Levt $_{\text {and }}$ Size $e_{i, t}$ represent risk management, leverage ratio and size of the firm $i$ at time $t$, respectively. In addition, $D P R_{i, t}, R E T_{i, t}$ and $L I Q_{i, t}$ represent dividend per share, return on equities and shares liquidity of the firm $i$ at time $t$, respectively. In this survey, Earning Volaltility ${ }_{i, t}$ is the dependent variable and is calculated as follows, 


$$
\mathrm{E}_{\mathrm{t}}=\alpha+\beta \mathrm{E}_{\mathrm{t}-1}+\varepsilon
$$

where $E_{t}$ and $E_{t-1}$ represent the earnings of two consecutive years, $\alpha$ represents the intercept and $\varepsilon$ indicates the error term. Moreover, earnings volatility is calculated using the variances of the earnings as follows,

$$
\operatorname{Var}(E t)=\beta^{2} \operatorname{Var}(E t-1)+\operatorname{Var}(\varepsilon),
$$

with

$$
\operatorname{Var}(\varepsilon)=\operatorname{Var}\left(E_{t}\right)\left(1-\beta^{2}\right) .
$$

The coefficient of sales variation has been used to measure environmental uncertainty. Because, the more the sales fluctuate, the company's business environment is more uncertain.

$$
E U i, t=\frac{\sigma \text { Sales }}{\mu \text { Sales }}
$$

Here $E U i, t$ represents indicates the coefficient of variation in sales and the index of the variability of environmental uncertainty, $\sigma$ Sales and $\mu$ Sales express the standard deviation and the mean of company sales over a period. In addition, Leverage is calculated as the ratio of total liabilities on total assets. Company size is calculated by taking the natural logarithm of the company's equity market value. Generally, companies that are bigger in size will have less commercial risk due to access to more product markets and economies of scale in affecting the factors of production, and they are more resistant to commercial disadvantages. Dividends ratio is the percentage of profit attributable to equity holders. Shareholders, with the exception of a company, pay two benefits from their investments, one is the difference between the selling price and the purchase price of the share, and the other is the profit of the stock.

Liquidity of the company: Liquidity ratios show the company's ability to meet short-term liabilities at maturity. Considering that the potential of the company in acquiring the necessary resources and creating growth opportunities depends on the company's liquidity, it is expected that with increasing liquidity, access to the required resources, timely fulfillment of obligations towards customers and creditors increase. To calculate the liquidity of the fast ratio, quick ratio is used as follows,

$$
\text { Quick ratio }=\frac{\text { Total assets }- \text { Inventory }}{\text { Total liabilities }} \text {. }
$$

\section{The results}

Table 1 shows some basic statistics of the data used in this survey.

\section{Table 1}

The results of some basic statistics

\begin{tabular}{cccccc}
\hline Variable & Mean & Median & Max & Min & Standard deviation \\
\hline Risk Management & 1.078 & 0.997 & 3.85 & 0.052 & 0.57 \\
Earnings volatility & 0.056 & 0.052 & 0.076 & 0.036 & 0.47 \\
Dividend per share & 0.63 & 0.71 & 1.93 & 0 & 0.36 \\
Firm size & 12.63 & 12.49 & 17.51 & 7.47 & 1.49 \\
Leverage & 0.65 & 0.66 & 0.97 & 0.10 & 0.17 \\
Return on equities & 0.232 & 0.10 & 1.86 & -0.79 & 0.53 \\
Quick ratio & 0.74 & 0.68 & 3.79 & 0.07 & 0.43 \\
\hline
\end{tabular}

Before model estimation, it is necessary to perform the F Limer test in order to investigate the use of panel data method in comparison with the pool method. The results of the implementation of Limer test indicates F-value $=3.48$ with P-value $=0.000$, which means we need to perform Panel data method with fixed effects. The Hausman test can be also applied to differentiate between fixed and random effects model in panel data. In this case, Random effects (RE) is suggested under the null hypothesis 
due to higher efficiency, while under the alternative Fixed effects (FE) is at least as consistent and thus preferred. In our survey, Hausman test yields a statistics of 44.31 with Sig. $=0.000$ which means Panel data with fixed effects must be used. Table 2 demonstrates the results of the survey.

Table 2

The results of the implementation of regression technique

\begin{tabular}{cccc}
\hline Variable & Coefficient & t-student & P-value \\
\hline Intercept & 1.81 & 3.6 & 0.000 \\
Risk management & -0.20 & 3.15 & 0.002 \\
Dividend per share & 0.023 & 0.023 & 0.026 \\
Firm size & 0.071 & 0.071 & 0.009 \\
Leverage & 0.231 & 0.231 & 0.148 \\
Share return & 0.0053 & 0.0053 & 0.000 \\
Liquidity & 0.059 & 0.059 & 0.048 \\
\hline
\end{tabular}

F-value $=9.77(0.000)$ R-Square $=0.85 \quad$ Adjusted R-Square $=0.83$ Durbin-Watson $=1.87$

According to the results shown in Table 2 and with the result of F-value $=9.77$ and its probability value (0.000), it can be stated that at $99 \%$ confidence level, in total, the pattern of the research has a high significance. Also, according to the adjusted adjustment coefficient obtained for the model that is equal to $85 \%$, it can be stated that in total, independent variables as well as control variables account for more than $85 \%$ of the dependent variable variations. In addition, according to the Durbin-Watson camera's size, which is 1.87 , it can be stated that there is no first-order correlation among the model's residuals. Also, the results show that the variables of dividend profit ratio with coefficient $(0.023)$, company size with coefficient (0.071) and liquidity ratio with coefficient $(0.059)$ at $5 \%$ level have a positive and significant relation with earnings volatility.

\subsection{First hypothesis}

In this hypothesis, the effect of risk management on the volatility of the profits of the accepted banks in Tehran Stock Exchange has been investigated. According to the results obtained in Table 2, the estimation of the research model and the coefficient of variable of risk management $(-0.20)$ and its probability value is significant (0.202), and it can be stated that in the probability value acceptable 5\%, the risk management variable has a negative and significant effect on the fluctuation of earnings of banks. The results of the research showed that risk management had a significant effect on the volatility of the companies that were accepted in Tehran Stock Exchange.

\subsection{Second hypothesis}

In this hypothesis, we examine the effect of stock return on the volatility of the profits of accepted banks in Tehran Stock Exchange. According to the results obtained in Table 2, the estimation of the research pattern and the coefficient of the stock return variable $(0.0005)$ and its probability value $(0.000)$, it can be stated that in the probability value of $5 \%$, stock return variables have a positive and significant effect on corporate risk management.

\section{Conclusion}

The purpose of this study was to examine the effect of risk management on the volatility of profits in listed companies in Tehran Stock Exchange. To calculate the volatility in the Dichev and Tang (2009) theoretical framework and to measure risk management, the environmental uncertainty index was used. The results of the study showed that risk factors have significant negative effects on the volatility of the listed companies in Tehran Stock Exchange. With regard to the overall results, it can be argued that investors invest heavily in projects that are more confident in gaining profit, that is, less fluctuation, and the results show that the higher the fluctuation, the higher is the return on the company. Therefore, profit is the most important product of the accounting system, whose main purpose is to provide the necessary information for performance evaluation and the ability to predict future cash flows. Therefore, volatility of profit is one of the most important criteria in the decision of investors, thus reducing the risk of volatility of profits in banks. For future studies, it is possible to study the 
relationship between quality of earnings and risk management and we leave it for interested researchers as a future study.

\section{References}

Aghabaki, M., Molaei, I., \& Maleki, H. (2012).The investigation of relationship between volatile and predictable earnings in accepted companies of Tehran Stock Exchange (TSE ). Journal of Basic and Applied Scientific Research, 2(4), 4258-4261.

Alijoyo, A. (2004). Focused enterprise risk management. MA:Addison-Wesley.

Basu, S. (1997). The conservatism principle and the asymmetric timeliness of earnings. Journal of Accounting and Economics, 24(1), 3-37.

Beaver, W., Kettler, P., \& Scholes, M. (1970). The association between market determined and accounting determined risk measures. The Accounting Review, 45(4), 654-682.

Beaver, W. H., \& Ryan, S. G. (2005). Conditional and unconditional conservatism: Concepts and modeling. Review of Accounting Studies, 10(2), 269-309.

Boltz, J. (1999). Informational Security Risk Assessment: Practices of Leading Organizations. DIANE Publishing.

Dichev, I. D., \& Tang, V. W. (2009). Earnings volatility and earnings predictability. Journal of Accounting and Economics, 47(1), 160-181.

Donelson, D. C., Jennings, R., \& McInnis, J. (2011). Changes over time in the revenue-expense relation: Accounting or economics?. The Accounting Review, 86(3), 945-974.

Frankel, R., \& Litov, L. (2009). Earnings persistence. Journal of Accounting and Economics, 47(12), 182-190.

Graham, J. R., Harvey, C. R., \& Rajgopal, S. (2005). The economic implications of corporate financial reporting. Journal of Accounting and Economics, 40(1), 3-73.

Gul, F. A., Tsui, J. S., \& Chen, C. J. (1997). Agency costs and audit pricing: Evidence on discretionary accruals.

Hamilton, J. L. (1978). Marketplace organization and marketability: NASDAQ, the stock exchange, and the national market system. The Journal of Finance, 33(2), 487-503.

Hutton, A. P., \& Stocken, P. C. (2009). Prior forecasting accuracy and investor reaction to management earnings forecasts.

Jensen, M. C., \& Meckling, W. H. (1976). Theory of the firm: Managerial behavior, agency costs and ownership structure. Journal of Financial Economics, 3(4), 305-360.

Kabir, M. H., \& Hassan, M. K. (2005). The near-collapse of LTCM, US financial stock returns, and the fed. Journal of Banking \& Finance, 29(2), 441-460.

Kolapo, T. F., Ayeni, R. K., \& Oke, M. O. (2012). Credit risk and commercial banks' performance in Nigeria: A panel model approach. Australian Journal of Business and Management Research, 2(2), 31.

Lewellen, J., \& Shanken, J. (2002). Learning, asset-pricing tests, and market efficiency. The Journal of Finance, 57(3), 1113-1145.

Louis, H. (2005). Acquirers' abnormal returns, audit firm size, and the small auditor clientele effect. Journal of Accounting and Economics, 40,75-99.

Ni, S. W., Fah, C. F., \& Nassir, A. M. (2009). The effect of financial risk on the earnings response in Thailand banks' stock. International Research Journal of Finance and Economics, 31, 55-65.

Ravindran, A. R., Ufuk Bilsel, R., Wadhwa, V., \& Yang, T. (2010). Risk adjusted multicriteria supplier selection models with applications. International Journal of Production Research, 48(2), 405-424.

Stulz, R. M. (2003). Risk management and derivatives. South-Western Pub.

Tang, O., \& Musa, S. N. (2011). Identifying risk issues and research advancements in supply chain risk management. International Journal of Production Economics, 133(1), 25-34.

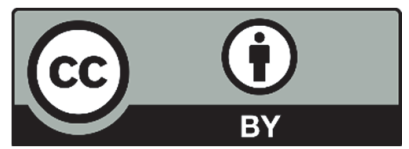

(C) 2017 by the authors; licensee Growing Science, Canada. This is an open access article distributed under the terms and conditions of the Creative Commons Attribution (CC-BY) license (http://creativecommons.org/licenses/by/4.0/). 